augmented histamine response. A notable example was the difference between the two sexes, the males secreting more acid than the females. It was of interest to see whether this difference was quantitatively the same with each of the different methods of expressing the augmented histamine response. Table III shows that the male/female ratios for all three methods were virtually identical, as were the Student's $t$ test values for each.

TABLE III.-Comparison of Differences Between Male and Female Preoperative Augmented Histamine Responses with the Three Methods of Expression (Standard Deviations in Parentheses)

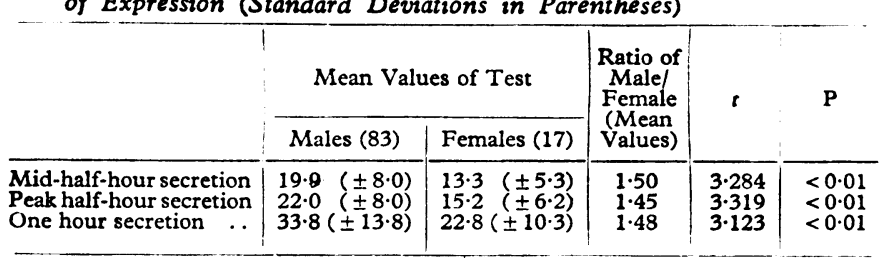

Finally, the effect of taking the three different estimates of augmented histamine response was observed in comparing two subgroups whose responses differed by a much smaller amount. These were the group with a negative response to insulin and the group with a small positive response occurring late in the two-hour collection period after the insulin injection. Though the classification of this late type of insulin response was made on an arbitrary basis, it had previously been found that the reduction in augmented histamine response due to vagotomy in patients comprising this subgroup was greater than the reduction in those with large and early positive insulin responses, and only slightly less than the reduction seen in those with completely negative insulin responses (Ross and Kay, 1964). Table IV shows that the relation between the two insulin groups is virtually the same regardless of the method used to express the augmented histamine responses.
TABLE IV.-Comparison of Percentage Reduction in Augmented Histamine Response in Patients with a Negative Insulin Test, and Those with a "Late Pcsitive" Insulin Test After Vagotomy and Drainage (Standard Deviations in Parentheses)

\begin{tabular}{|c|c|c|c|c|c|}
\hline & \multicolumn{2}{|c|}{$\begin{array}{l}\text { Percentage Reduction of Aug- } \\
\text { mented Histamine Response }\end{array}$} & \multirow{2}{*}{$\begin{array}{l}\text { Ratio of } \\
\text { \% Reduc- } \\
\text { tions: } \\
\text { Negative/ } \\
\text { Positive }\end{array}$} & \multirow{2}{*}{$t$} & \multirow{2}{*}{$\mathbf{P}$} \\
\hline & $\begin{array}{c}\text { Insulin } \\
\text { Negative } \\
(69 \text { cases })\end{array}$ & $\begin{array}{l}\text { Insulin " Late } \\
\text { Positive" } \\
\text { (27 cases) }\end{array}$ & & & \\
\hline $\begin{array}{l}\text { Mid-half-hour out- } \\
\text { put } \\
\text { Peak half-hour out- }\end{array}$ & $75 \%( \pm 18 \cdot 3)$ & $56 \%( \pm 19 \cdot 3)$ & $1 \cdot 34$ & $4 \cdot 551$ & $<0.01$ \\
\hline $\begin{array}{l}\text { put } \\
\text { One hour output.. }\end{array}$ & $\begin{array}{l}69 \%( \pm 17 \cdot 5) \\
73 \%( \pm 18 \cdot 9)\end{array}$ & $\begin{array}{l}54 \%( \pm 20 \cdot 8) \\
58 \%( \pm 20 \cdot 4)\end{array}$ & $\begin{array}{l}1 \cdot 28 \\
1 \cdot 26\end{array}$ & $\begin{array}{l}3 \cdot 579 \\
3 \cdot 377\end{array}$ & $\begin{array}{l}<0.01 \\
<0.01\end{array}$ \\
\hline
\end{tabular}

\section{Conclusions and Summary}

It can be seen from Tables I and II that there was a highly significant degree of correlation between the three methods of expressing the results. Tables III and IV show that when differences exist between the results of subgroups of patients within the series these differences are of the same magnitude, regardless of the way in which the results are expressed.

We therefore conclude that variations in the method of expressing the results of the augmented histamine test are unlikely to alter the conclusions derived from a particular series of such tests. It is likely, therefore, that conclusions in studies using different ways of expressing the test responses can be directly related one with another.

\section{REFERENCES}

Baron, J. H. (1963). Gut, 4, 136.

Bruce, J., Card, W. I., Marks, I. N., and Sircus, W. (1959). F. roy. Coll. Surg. Edinb., 4, 85.

Gillespie, I. E., and Kay, A. W. (1961). Brit. med. F., 1, 1557.

Hollander, F. (1951). Meth. med. Res., 4, 166.

Kay, A. W. (1953). Brit. med. Y., 2, 77.

Ross, B., and Kay, A. W. (1964). Gastroenterology, 46, 379.

\title{
Late Changes in Peripheral Blood after Thorotrast Administration
}

\author{
A. O. LANGLANDS,* M.B., CH.B., B.SC., D.M.R.T., F.F.R.; E. R. D. WILLIAMSON,* M.B., B.CH.
}

Brit. med. F., 1967, 3, 206-208

From its introduction in 1930 a stabilized colloidal suspension of ${ }^{232}$ thorium dioxide (Thorotrast) was extensively used either to outline body cavities, such as the renal pelvis or the paranasal sinuses after direct injection, or as a contrast medium in angiography, and, after deposition, for visualization of the liver and spleen. Its use was largely discontinued in 1947 after the report of MacMahon et al. (1947) on the first malignancy due to Thorotrast. Horta et al. (1965) reported a follow-up study of some 1,100 persons who had received Thorotrast. In addition to malignancies arising at sites of Thorotrast deposition 16 deaths out of a total of 699 were due to leukaemia, aplastic anaemia, or purpura.

We have recently undertaken a study of patients who had received intra-arterial Thorotrast, in an attempt to obtain information on the morbidity and haematological and cytogenetic changes due to Thorotrast. The purpose of this communication is to report the findings on examination of peripheral blood from these patients.

* M.R.C. Clinical Effects of Radiation Research Unit, Western General Hospital, Edinburgh 4.

\section{Material and Methods}

Between 1930 and 1947, during investigation in the department of surgical neurology, Edinburgh, 137 patients received intra-arterial Thorotrast. In 1966 there were 37 survivors still residing in Edinburgh or near by. A venous blood sample was obtained from 35, comprising 18 men and 17 women. With one exception all had received Thorotrast before 1947.

The details of Thorotrast administration in these patients are summarized in Table $\mathrm{I}$.

Packed cell volumes were determined according to the method described by Dacie and Lewis (1963); haemoglobin was esti-

TABLB I

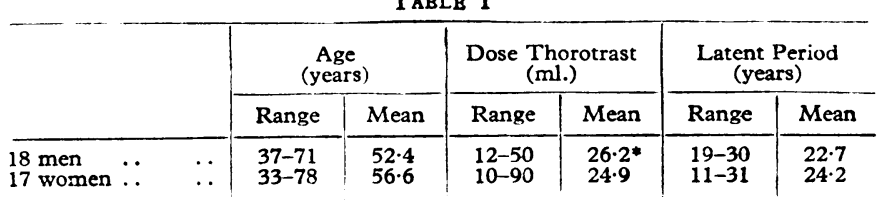

* Based on 13 cases. The dose was unrecorded in five. 
mated photoelectrically as oxyhaemoglobin; white blood cells and platelets were counted, after bulk dilution, in a new Neubauer counting-chamber. Films made from fresh blood were air-dried, fixed in methanol for 10 minutes, and stained by May-Grunwald-Giemsa.

Absolute values for polymorphonuclear leucocytes, lymphocytes, monocytes, and eosinophils were calculated using the total white cell count and a differential white cell count based on 200 cells.

\section{Results}

In all 35 patients the packed cell volume, haemoglobin level, white cell count, and platelet count were within the normal range. A few patients showed a relative lymphocytosis, but the mean values for the differential white cell count did not differ described in detail, in which Howell-Jolly bodies were reported in non-splenectomized patients. Of these, three were cases of pernicious anaemia with haemoglobin levels in the region of $60-70 \%$, and one was a case of carcinomatosis with a haemoglobin level of $20 \%$.

The finding of Howell-Jolly bodies in erythrocytes in 34 out of our 35 cases is therefore all the more striking in view of the otherwise normal haematological findings in these patients (Table II).

Howell-Jolly bodies have been demonstrated in the later erythroblasts in cases of vitamin- $B_{12}$ or folic-acid deficiency (Hutchison and Ferguson-Smith, 1959 ; Dawson and Bury, 1961 ; Fraser et al., 1966). The last-mentioned authors, in contrast to Hutchison and Ferguson-Smith, also demonstrated Howell-Jolly bodies in erythroblasts after splenectomy. We

TABLE II

\begin{tabular}{|c|c|c|c|c|c|c|c|c|c|c|c|c|c|c|c|c|}
\hline & \multicolumn{2}{|c|}{ P.C.V. } & \multicolumn{2}{|c|}{$\underset{\text { (g. } / 100 \mathrm{ml} .)}{\mathrm{Hb}}$} & \multicolumn{2}{|c|}{$\begin{array}{c}\text { W.B.C. } \\
\left(\times 10^{3} / \mathrm{cu} . \mathrm{mm} .\right)\end{array}$} & \multicolumn{2}{|c|}{$\begin{array}{c}\text { Platelets } \\
\left(\times 10^{3} / \text { cu. mm. }\right)\end{array}$} & \multicolumn{2}{|c|}{ Neutrophils } & \multicolumn{2}{|c|}{ Lymphocytes } & \multicolumn{2}{|c|}{ Monocytes } & \multicolumn{2}{|c|}{ Eosinophils } \\
\hline & Range & Mean & Range & Mean & Range & Mean & Range & Mean & $\begin{array}{c}\times 10^{3} ! \\
\text { cu. } \mathrm{mm} .\end{array}$ & $\%$ & $\begin{array}{c}\times 10^{3} / \\
\mathrm{cu} . \mathrm{mm}\end{array}$ & $\%$ & /cu. mm. & $\%$ & /cu. mm. & $\%$ \\
\hline $\begin{array}{l}18 \text { men ... } \\
17 \text { women }\end{array}$ & $\begin{array}{l}41 \cdot 0-52 \cdot 0 \\
35 \cdot 5-48 \cdot 0\end{array}$ & $\begin{array}{l}45 \cdot 6 \\
40 \cdot 9\end{array}$ & $\begin{array}{l}11 \cdot 2-16 \cdot 4 \\
10 \cdot 5-14 \cdot 9\end{array}$ & $\begin{array}{l}14 \cdot 3 \\
12 \cdot 7\end{array}$ & $\begin{array}{l}5 \cdot 0-13 \cdot 6 \\
4 \cdot 85-9 \cdot 05\end{array}$ & $\begin{array}{l}6 \cdot 6 \\
6 \cdot 7\end{array}$ & $\begin{array}{l}174-262 \\
140-358\end{array}$ & $\begin{array}{l}219 \\
220\end{array}$ & $\begin{array}{l}3 \cdot 38 \\
3 \cdot 44\end{array}$ & $\begin{array}{l}51 \\
51\end{array}$ & $\begin{array}{l}2 \cdot 58 \\
2 \cdot 58\end{array}$ & $\begin{array}{l}39 \\
38\end{array}$ & $\begin{array}{l}440 \\
410\end{array}$ & $\begin{array}{l}6 \cdot 6 \\
6 \cdot 1\end{array}$ & $\begin{array}{l}200 \\
250\end{array}$ & $\begin{array}{l}3 \cdot 0 \\
3 \cdot 7\end{array}$ \\
\hline
\end{tabular}

significantly from the normal values given by Dacie and Lewis (1963). The mean values are shown in Table II.

The most striking feature on examination of peripheral blood films was a disturbance of red cell morphology. There was a varying degree of anisocytosis, with occasional well-filled macrocytes, and, in addition, numerous burr cells and occasional target cells and stipple cells were present. Giant platelets were a common finding. Howell-Jolly bodies were present in 34 out of 35 films, the exception being that of a woman of 55 who, 23 years previously, had received $40 \mathrm{ml}$. of Thorotrast during right carotid angiography. On examination of her neck a hard mass was found at the site of injection. $X$-ray films showed this to be a dense aggregation of Thorotrast. Virtually no Thorotrast was visible in the spleen on abdominal $x$-ray examination.

In each of eight patients 1,000 red cells were counted, the percentages of abnormal cells being recorded in Table III. Fig. 1 shows a field from a peripheral blood film which illustrates these findings.

TABLE III

\begin{tabular}{|c|c|c|c|c|c|c|c|c|}
\hline \multirow{2}{*}{$\begin{array}{l}\text { Case } \\
\text { No. }\end{array}$} & \multirow{2}{*}{$\begin{array}{c}\text { Sex and } \\
\text { Age }\end{array}$} & \multirow{2}{*}{$\begin{array}{c}\text { Thoro- } \\
\text { trast } \\
\text { (ml.) }\end{array}$} & \multirow{2}{*}{$\begin{array}{l}\text { Latent } \\
\text { Period } \\
\text { (years) }\end{array}$} & $\begin{array}{l}\text { Burr } \\
\text { Cells }\end{array}$ & $\begin{array}{c}\text { Target } \\
\text { Cells }\end{array}$ & $\begin{array}{l}\text { Stipple } \\
\text { Cells }\end{array}$ & $\begin{array}{c}\text { H.J. } \\
\text { Bodies }\end{array}$ & \multirow{2}{*}{$\begin{array}{c}\text { Giant } \\
\text { Platelets }\end{array}$} \\
\hline & & & & \multicolumn{4}{|c|}{ Per 100 Red Blood Cells } & \\
\hline $\begin{array}{l}1 \\
2 \\
3 \\
4 \\
5 \\
6 \\
7 \\
8\end{array}$ & $\begin{array}{ll}\mathrm{F} & 61 \\
\mathrm{~F} & 42 \\
\mathrm{~F} & 51 \\
\mathrm{~F} & 40 \\
\mathrm{M} & 60 \\
\mathrm{M} & 54 \\
\mathrm{M} & 55 \\
\mathrm{M} & 56\end{array}$ & $\begin{array}{l}18 \\
45 \\
90 \\
20 \\
26 \\
38 \\
36 \\
14\end{array}$ & $\begin{array}{l}11 \\
30 \\
21 \\
23 \\
24 \\
25 \\
20 \\
25\end{array}$ & $\begin{array}{r}7 \\
7 \\
2 \\
7 \\
12 \\
8 \\
6 \\
2\end{array}$ & $\begin{array}{l}5 \\
1 \\
1 \\
1 \\
2 \\
2 \\
2 \\
1\end{array}$ & $\begin{array}{l}1 \\
1 \\
1 \\
1 \\
1 \\
1 \\
1 \\
1\end{array}$ & $\begin{array}{l}0.8 \\
0.9 \\
0.9 \\
0.5 \\
2.6 \\
1.5 \\
0.5 \\
0.5\end{array}$ & $\begin{array}{l}+ \\
+ \\
+ \\
+ \\
+ \\
+ \\
+ \\
+\end{array}$ \\
\hline
\end{tabular}

\section{Discussion}

The presence of Howell-Jolly bodies in erythrocytes is classically associated with removal of the spleen but also occurs in congenital absence of the spleen (Bush and Ainger, 1955), in the splenic atrophy which is occasionally associated with steatorrhoea (Boveri, 1942 ; Fraser et al., 1966), and in a variety of dyshaemopoietic states such as megaloblastic anaemia and leukaemia (de Gruchy, 1964). Nevertheless, the finding of Howell-Jolly bodies in erythrocytes is a rare event in the absence of a history of splenectomy. Boveri reviewed all the haematological reports for a five-year period at Guy's Hospital and could find only seven cases, in addition to the two he have been able to examine only two marrow preparations from Thorotrast patients, both of whom had Howell-Jolly bodies in erythrocytes. In neither case were Howell-Jolly bodies seen in marrow erythroblasts.

The presence of burr cells is a less reliable index of a disturbance of splenic function and occurs in other diverse conditions such as glomerulonephritis and gastric carcinoma (Schwartz and Motto, 1949). In microangiopathic haemolytic anaemia

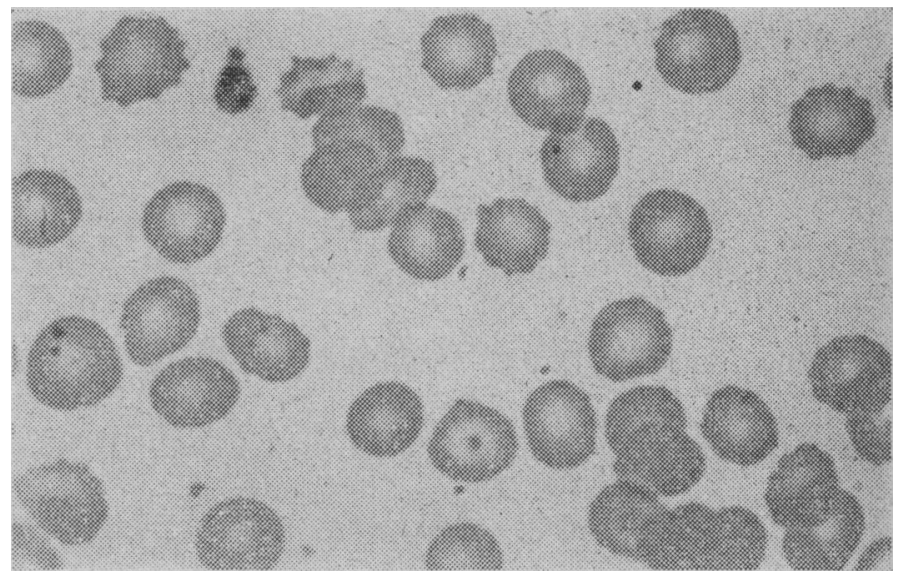

Fig. 1.-Peripheral blood. $(\times 1,110$.

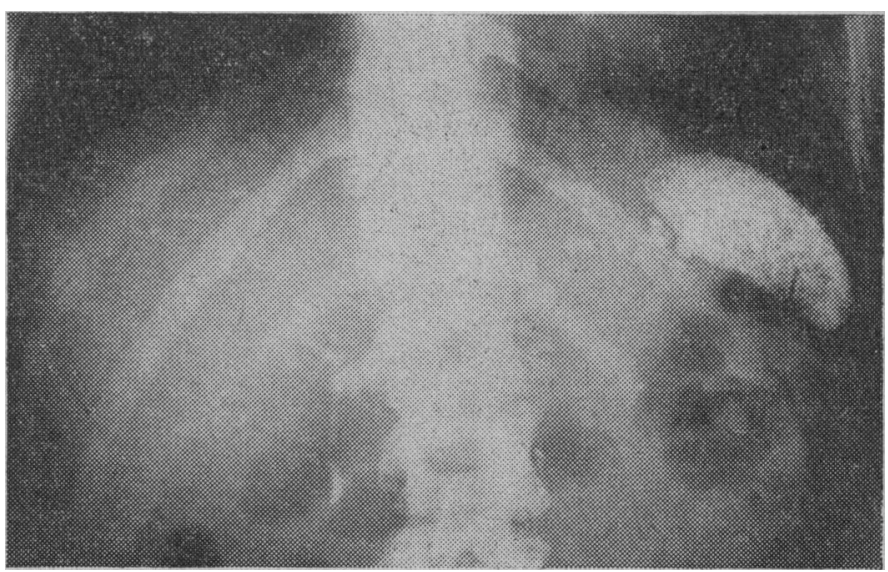

FIG. 2.-Straight $x$-ray film of abdomen. 
direct contact between erythrocytes and damaged blood vessels may be a factor in the production of burr cells (Brain et al., 1962). Burr cells were present in all cases that we examined.

The peripheral blood film in our patients is therefore in many ways similar to that seen after removal of the spleen. In two patients the level of Howell-Jolly bodies was greater than that said to occur after splenectomy ( $0.3 \%$ of erythrocytes) and was closer to the higher values (3.9-5.3\% of erythrocytes) which Fraser et al. reported in three cases of splenic atrophy associated with steatorrhoea.

The significance of these findings, we believe, is twofold. Firstly, the sequelae of Thorotrast characteristically occur after a long latent period-of the order of 20 years or more-and most patients are unaware that the injection has been made. In the absence of a history of splenectomy previous Thorotrast administration may be suspected when the peripheral blood film shows the changes usually associated with removal of the spleen. This is particularly so when haematological examination is otherwise normal.

Secondly, these changes may be indicative of a progressive loss of splenic function in patients exposed to Thorotrast. After intravascular injection the particles of thorium are phagocytosed by reticuloendothelial cells and are deposited mainly in the spleen and liver, and to a lesser extent in the bone marrow. Fig. 2 shows the appearances of heavy deposits of thorium in the spleen of a 33-year-old woman who at the age of 13 had $20 \mathrm{ml}$. of Thorotrast injected into the left carotid artery.

Attempts to estimate dosage to the spleen from the radioactive material deposited there are for technical reasons extremely difficult, but the dosage has been calculated by Rundo (1955) to be in the region of $1,100-1,300 \mathrm{rep}^{1}$ of $\alpha$-rays and 130-150 rep of $\beta$-rays 20 years after an injection of $20 \mathrm{ml}$. of Thorotrast. As a result of this irradiation, and the interstitial fibrosis which follows the deposition of thorium in tissues, it is not unreasonable to postulate that over the years there will be a progressive loss of splenic function in these patients, and that this will underlie the peripheral blood changes we have described. The careful study and follow-up of such cases may therefore provide useful information regarding the effects of the loss of splenic function and its possible role in some of the sequelae of Thorotrast administration.

\section{Summary}

Thirty-five persons who had received intra-arterial Thorotrast 11 or more years previously were examined. A consistent finding in films of peripheral blood was a disturbance of red cell morphology and the presence of Howell-Jolly bodies. In the absence of splenectomy, and when haematological examination is otherwise normal, such findings are extremely rare. It is thought likely that a progressive loss of splenic furction has occurred in these patients as a result of irradiation and that this has caused the peripheral blood changes which we have described. More refined studies of splenic function in such patients are indicated.

We are grateful to Professor Norman Dott, Professor John Gillingham, Dr. Kate Herman, and Mr. Jeffrey Maccabe for access to their case records and permission to study patients under their care. Dr. J. T. Boyd, of the M.R.C. Radiation Registry, kindly provided follow-up information. We are also grateful to Miss Zoe Fotheringham for help in tracing patients.

\section{REFERENCES}

Boveri, R. M. (1942). Guy's Hosp. Rep., 91, 81.

Brain, M. C., Dacie, J. V., and Hourihane, D. O'B. (1962). Brit. 7. Haemat., 8, 358.

Bush, J. A., and Ainger, L. E. (1955). Pediatrics, 15, 93.

Dacie, J. V., and Lewis, S. M. (1963). Practical Haematology, 3rd ed. London.

Dawson, D. W., and Bury, H. P. R. (1961). f. clin. Path., 14, 374.

de Gruchy, G. C. (1964). 'Clinical Haematology in Medical Practice, 2nd ed. Oxford.

Fraser, I. D., McCarthy, C. F., and Read, A. E. (1966). F. clin. Path., $19,190$.

Horta, J. da S., Abbatt, J. D., da Motta, L. C., and Roriz, M. L. (1965). Lancet, 2, 201.

Hutchison, H. E., and Ferguson-Smith, M. A. (1959). f. clin. Path., 12 451 .

MacMahon, H. E., Murphy, A. S., and Bates, M. I. (1947). Amer. \}. Path., 23, 585

Rundo, J. (1955). Brit. \%. Radiol., 28, 615.

Schwartz, S. O., and Motto, S. A. (1949). Amer. f. med. Sci., 218, 563.

${ }^{3}$ Roentgen equivalent physical.
A woman aged 59 was well until December 1958, when severe pain developed in the left side of her face after the extraction of a left upper wisdom tooth. The left nostril was obstructed and discharged pus. After antral washouts these symptoms were to some extent relieved.

In February 1959, after taking a hot bath, she noticed that the index and middle fingers of the left hand had become numb and white. The left middle finger was painful, and there was an area

* University College Hospital, London W.C.1.

t Present address: Aberdeen Royal Infirmary. of discoloration at its tip, which later became black. A persistent pain, severe enough to prevent sleep, developed in the finger.

A year before this episode her right foot had become cold and white, and she had felt a pain in her right calf on walking uphill. Tolazoline hydrochloride was given by her doctor, and these symptoms soon disappeared. She habitually smoked 20 cigarettes a day. In 1949 she had had a gastroenterostomy for duodenal ulcer.

The severe pain led to her admission to hospital. On examination her general appearance was of good health, but there was a slight swelling of the left side of her face. The terminal phalanx of the left middle finger was black and dry. Adjacent to this was an area of painful erythema. The remainder of the finger was swollen and fixed in the extended position. There was a small area of discoloration on the pulp of the left index finger (see Fig. 1). Both fingers were colder than the other fingers of the left hand. Her blood pressure was $150 / 90$, and the peripheral pulses, including the brachials and radials, were present and normal. There was no evidence of heart disease. Clinical examination was in all other respects normal.

Investigations.- $\mathrm{Hb} 67 \%$. W.B.C. 10,200/cu. mm., normal differential count. No L.E. cells. E.S.R. $50 \mathrm{~mm} . / \mathrm{hr}$. Electro- 